\title{
Economic review
}

\section{May 2010}

Graeme Chamberlin

Office for National Statistics

\section{SUMMARY}

The Preliminary estimate of Gross Domestic Product (GDP) reports that the UK economy grew by 0.2 per cent in 2010 Q1 - slightly weaker than the previous quarter when GDP expanded by 0.4 per cent. Previous work looking at the coherence of ONS and Purchasing Managers' Index (PMI) data is updated, which shows that PMI is suggesting a stronger recovery in activity than official data. Although unemployment increased to 8.0 per cent in DecemberFebruary 2010, the labour market has not weakened to the same extent as in the previous two recessions. Annual inflation in the Consumer Prices Index (CPI) picked up to 3.4 per cent in March, of which one-and-three-quarters percentage points is estimated to be accounted for by the reversion in the rate of VAT to 17.5 per cent in January 2010.

\section{UK economy expands by 0.2 per cent in first quarter of $\mathbf{2 0 1 0}$}

$\Lambda$ fter growing by 0.4 per cent in the final quarter of last year, Preliminary estimates of Gross Domestic Product (GDP) report that the UK economy expanded by 0.2 per cent in the first quarter of 2010. This, the second successive quarter of positive growth, follows six quarters of contraction where the level of GDP fell from peak to trough by around 6.2 per cent (Figure 1). As a result, output in the economy as whole and also in the production and services sub sectors, remains significantly below prerecession highs. The slowdown in growth from the first quarter may partly reflect the disruption caused by heavy snowfall across the country in January.

\section{Figure 1}

GDP growth

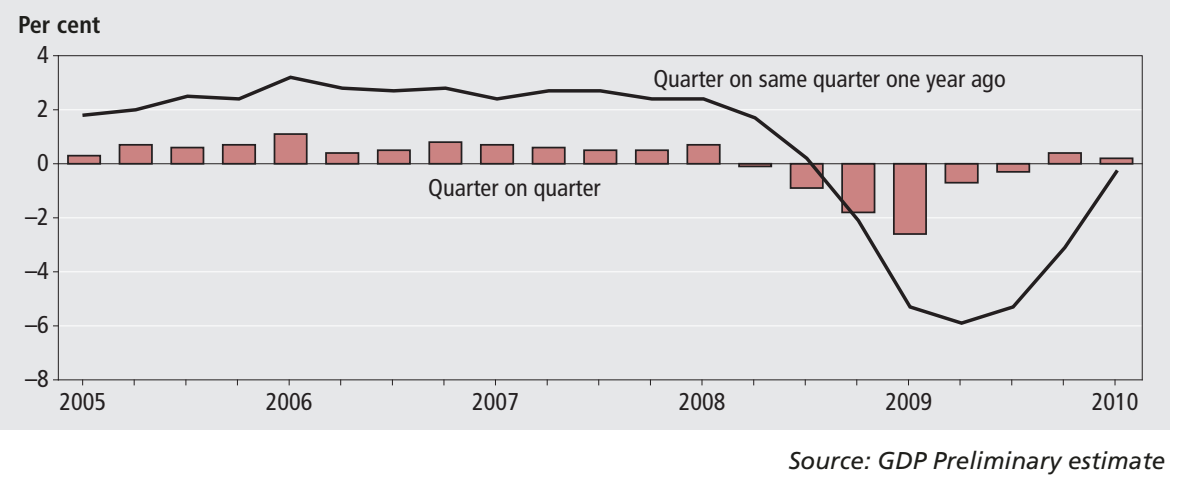

Monitoring the coherence between ONS and PMI data - an update

number of business groups and trade associations also provide indicators

of UK economic activity. Although these are usually more qualitative and based on smaller samples than official data, they are viewed by many as useful and timely indicators.

Purchasing Managers' Index (PMI) data are among the most prominent and widely used business surveys. For example, the Bank of England have stated that they place some emphasis on these surveys in forming their short-term view of the economy (see Ashley et al 2005 and Cunningham and Jeffery 2007).

Growing interest in this survey prompted ONS to investigate the coherence between PMI and National Accounts data, more specifically the monthly Index of Manufacturing and the monthly Index of Services. This analysis was first published in the appendix of Meader and Tily (2008) and a fuller description in Chamberlin (2008). A brief update of this work is now presented here.

PMI data is published by Markit Economics on behalf of the Chartered Institute of Purchasing and Supply (CIPS). Individual surveys for the manufacturing, construction and services sectors are published monthly. Although the indicators are very rapid, being published immediately after the reference quarter compared to 2325 days for the Preliminary GDP estimate, there are trade-offs in terms of sample sizes and detail.

The UK Manufacturing PMI is collected from a representative panel of around 600 companies. For construction the PMI sample size is 170 companies in the UK construction sector. And for the Services PMI, a monthly report is collected from around 700 companies. Each of these sample sizes are substantially smaller than the monthly surveys administered by ONS for the Index of Manufacturing (Production) and the Index of Services. Furthermore, PMI surveys simply ask respondents to state whether output or activity has 'gone up', 'remained unchanged' or 'gone down' in the latest month. The results are presented as balance statistics 


\section{Figure 2}

\section{Signal extraction: Index of Manufacturing and Manufacturing PMI}

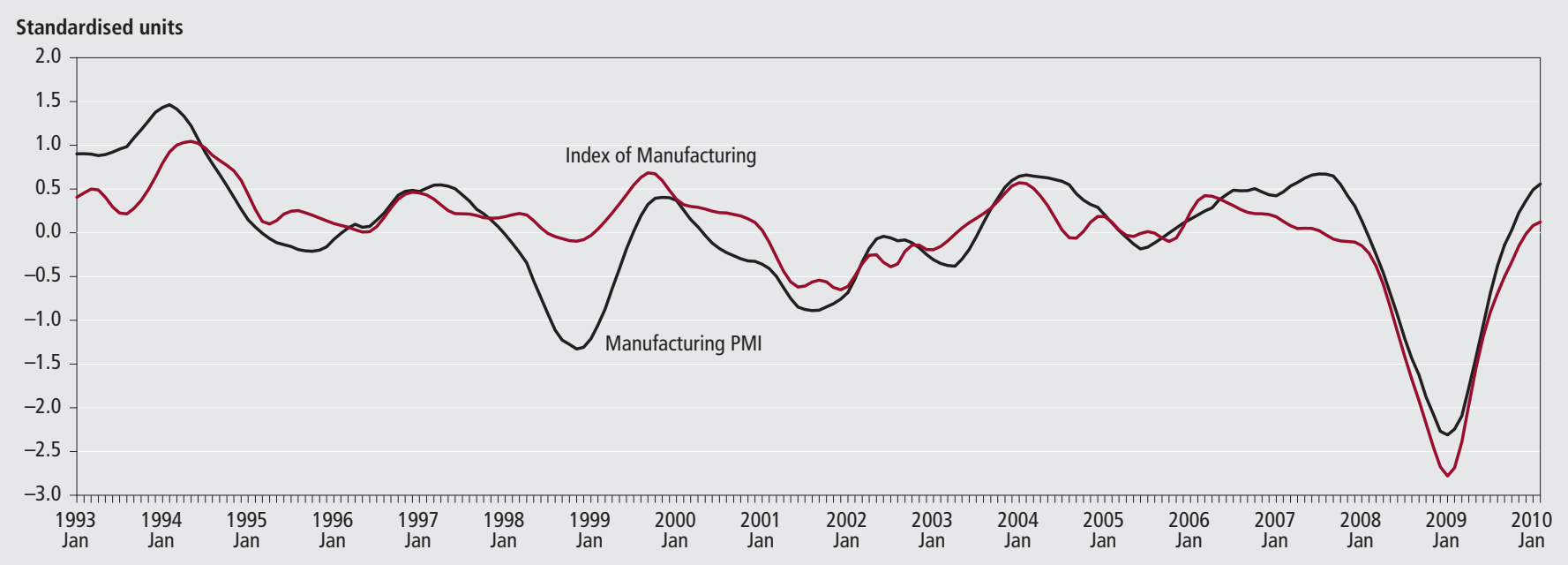

Source: Index of Manufacturing and UK Manufacturing PMI

between the proportion of firms reporting 'up' against 'down' and then normalised so that in aggregate: $50=$ no change, $0=$ unanimously down, and $100=$ unanimously up. Consequently, respondents cannot report an order of magnitude to output or activity changes over the month but only the direction, unlike in official data collections.

As ONS and PMI data are produced on different bases a number of transformations are necessary in order to make a comparison. This methodology is explained further in Chamberlin (2008) but briefly as follows:

- investigate correlation - ONS data is normally more strongly correlated with lags of PMI data. Whereas PMI data are monthly indicators, headline ONS data for the Index of Manufacturing and Index of Services are reported as three-months on three-months growth rates, hence more past data is included in the measure. It might also be the case that PMI data, by the very nature of qualitative business survey collections, are influenced by forward looking factors such as business confidence regarding the economic outlook. Therefore, in making a comparison it is sensible to consider lags of PMI

- standardise the units of measurement - ONS data is reported as a growth rate whereas PMI data as a balance statistic, so the measures are not directly comparable. There is a large literature on how balance statistic data may be mapped to continuous growth rates which is summarised by Nardo (2003). However, here we simply standardise both data sources, which reduces each to a time series with an average of zero and a standard deviation (hence variance) of unity

- signal extraction - the final stage is to use a Kalman Filter to capture the underlying trend in each time series by smoothing out transitory and erratic features of the data

The basic rationale in this approach is that both ONS and PMI are essentially trying to measure the same underlying economic activity or behaviour (which is referred to as the signal), although due to different methodologies and samples each will do so subject to different forms of measurement error. Coherence can then be judged by attempting to capture and compare these underlying signals in both data sources. For this the Kalman Filter is a standard tool for signal extraction problems.

Figure 2 presents the results of the signal extraction exercise for the manufacturing sector (up to and including February 2010). Clearly, both data sources reflect the significant downturn in UK manufacturing output during 2008 and the majority of 2009. Recent recovery in manufacturing growth towards the end of 2009 and early 2010 is also captured in both time series.

Latest published data (GDP Preliminary estimate) reports that manufacturing output increased by 0.7 per cent in 2010 Q1 following growth of 0.8 per cent in 2009 Q4. Prior to this the sector contracted for six consecutive quarters, registering a peak to trough fall in output of 14.0 per cent between 2008 Q1 and 2009 Q3.

According to the April UK Manufacturing PMI, output has remained above the $50=$ no change index for the tenth successive month, implying that the recovery in this sector started in July 2009. In fact, the April survey reported the highest positive balance since July 1994 and the second highest balance recorded in the 18 years of the survey.

The strength of the recovery in manufacturing output primarily reflected the improving general economic environment, in turn leading to growing new orders and efforts to reduce backlogs of work. New orders registered a ninth successive monthly increase as domestic and global conditions continued to improve. Of particular significance were increasing moves to rebuild inventories from their current low levels, especially stocks of raw materials. Although the pick up in growth was broad-based the sharpest increases in output and new orders were seen in the intermediate goods sector. Export orders increased for the seventh month with the exchange rate identified as a factor aiding competitiveness.

Comparing the ONS Index of Services with the UK Services PMI is more complicated as the coverage between the two is different. More specifically, around one half of the services sector (according to published Index of Services weights) are not actually covered by the PMI, including:

- Wholesale and distribution (153 parts per 1000 in GVA weights)

- Letting of dwellings (91)

- Public administration and defence (75)

- Education (80)

- Health and social services (85)

- Sewage and refuse disposal (9)

- Private households with employed persons (6)

Exclusion of these items may obviously 


\section{Figure 3}

\section{Index of Services and adjusted Index of Services}

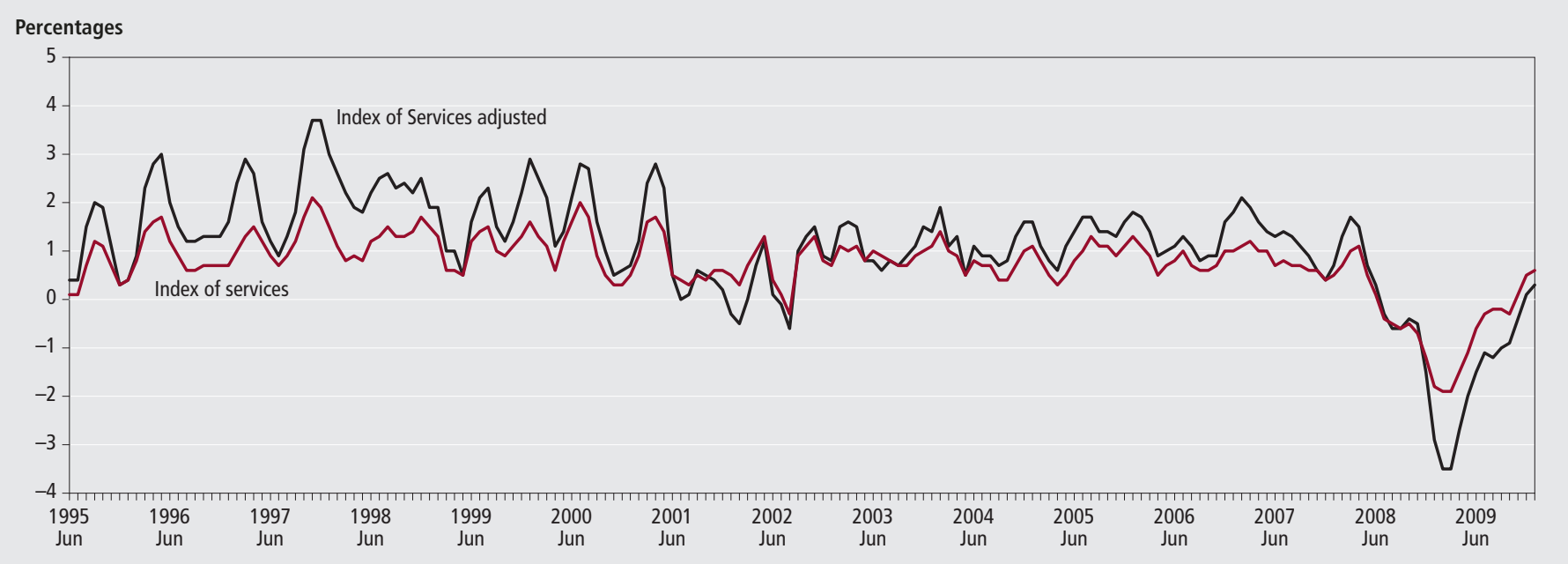

Source: Index of Services

lead to a divergence between the two data sources, especially if the above industries which tend to fall in the distribution and public services, behave differently to the rest of the services sector. As a result, PMI data tends to be more heavily influenced by activity in business services. Section JK in the Index of Services, that is business services and finance, accounts for around 310 parts per 1000 in GVA weights.

However, given what is excluded, its weight in the PMI survey may be approximately double that.

Figure 3 presents the three-months on three-months growth rates for the Index of Services and also for an adjusted series that attempts to remove the components that are not covered in Services PMI data.

One of the key features shown in Figure 3 is that the contraction in the adjusted Index of Services time series is much stronger than in the overall index. Considering the components that have been removed from the adjusted series this is not too surprising. Public administration and defence, education and health and social services, sewage and refuse disposal largely consist of public sector output, which tends to be relatively stable over the business cycle and less prone to significant contraction during a recession. Given that these industries account for almost a third of total services output they are likely to moderate the extent of the contraction.

Ownership of dwellings is also a relatively large and stable part of output accounting for around 10 per cent of services valueadded. This largely consists of the imputed rental activity of owner-occupiers who pay themselves to live in their own properties. As tenants of private and social landlords engage in market activity that is recorded in the National Accounts, failure to account for this otherwise non-recorded activity would make services output susceptible to shifts between the proportion of tenant and owner-occupied households. It would also make international comparisons of the level of GDP difficult where these proportions differ between countries. The implicit output of this owner-occupier industry also tends to be relatively stable regardless of activity in the wider economy as the real consumption of housing services would not be expected to show large cyclical variation.

The adjusted series, as previously mentioned, is therefore driven to a larger extent by the remaining industries of which business services and finance are a large constituent part. One of the characteristic features of the most recent recession compared to those previously was the extent to which it was driven by a contraction in business to business demand which impacted significantly on this industry. Transport and communication also contracted sharply in the recession which will be reflected more significantly in the adjusted series.

Figure 4 presents the results of the signal extraction exercise comparing the adjusted IoS with the Services PMI data (up to January 2010). Although the two time series show a good degree of coherence during the recession, it appears that the strength of recovery according to Services PMI data has been stronger.

The GDP preliminary estimate reported that services output grew by 0.2 per cent in the first quarter of this year, slower than the 0.5 per cent growth recorded in 2009 Q4. Prior to this the sector had contracted for five successive quarters between 2008 Q2 and 2009 Q3, as the level of output dropped from peak to trough by a total of 4.5 per cent.

UK Services PMI in April reported higher activity due to greater levels of new business after snow had affected activity at the beginning of the year. The rise in business activity, the eleventh successive month that the balance was above 50 , was down to an improvement in general economic conditions feeding through to business confidence.

Butler (2005) defines GDP* as a measure of (private sector) output consistent with the industries covered in PMIs for manufacturing, services and construction. $\mathrm{GDP}^{\star}$ can be constructed using the Index of Manufacturing, the adjusted Index of Services, and by interpolating (using a cubic spline) quarterly data on construction output. These component parts can then be weighted together using official GVA weights.

Figure 5 presents the results of the signal extraction procedure on an aggregate PMI and a measure of GDP* This primarily reflects the coherence issues shown in the services sector, which as the largest part of UK private sector output, is understandable. In both measures the depth and timing of the recent recession appear fairly consistent, but recovery is faster in the aggregated PMI.

Despite attempts to reconcile the two data sources it is not alarming that some differences still remain - a reflection that the two data sources are methodologically different. One key issue, which might explain why PMI data is rebounding faster than official estimates, is that survey respondents can only report in the direction of output or activity and not the speed. As a result, strong positive survey balances may 


\section{Figure 4}

\section{Signal extraction: Index of Services and PMI Services}

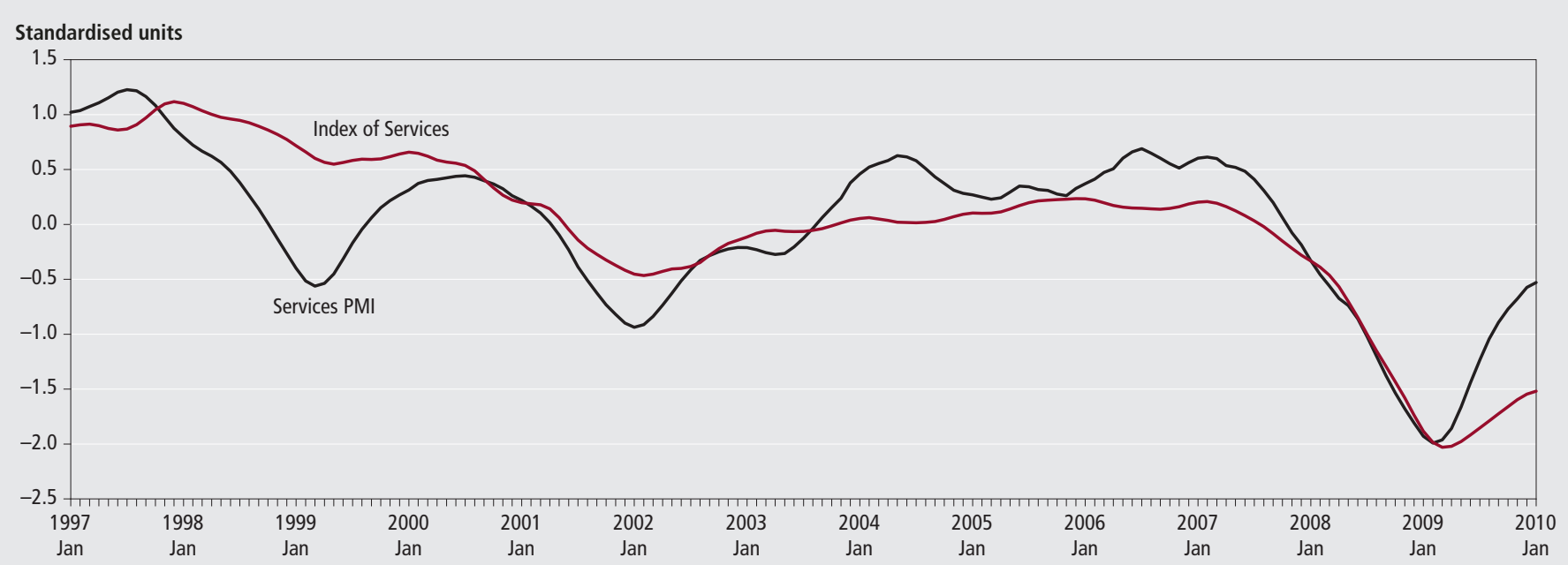

Source: Index of Services and UK Services PMI

\section{Figure 5}

\section{Signal extraction: Aggregate PMI and GDP*}

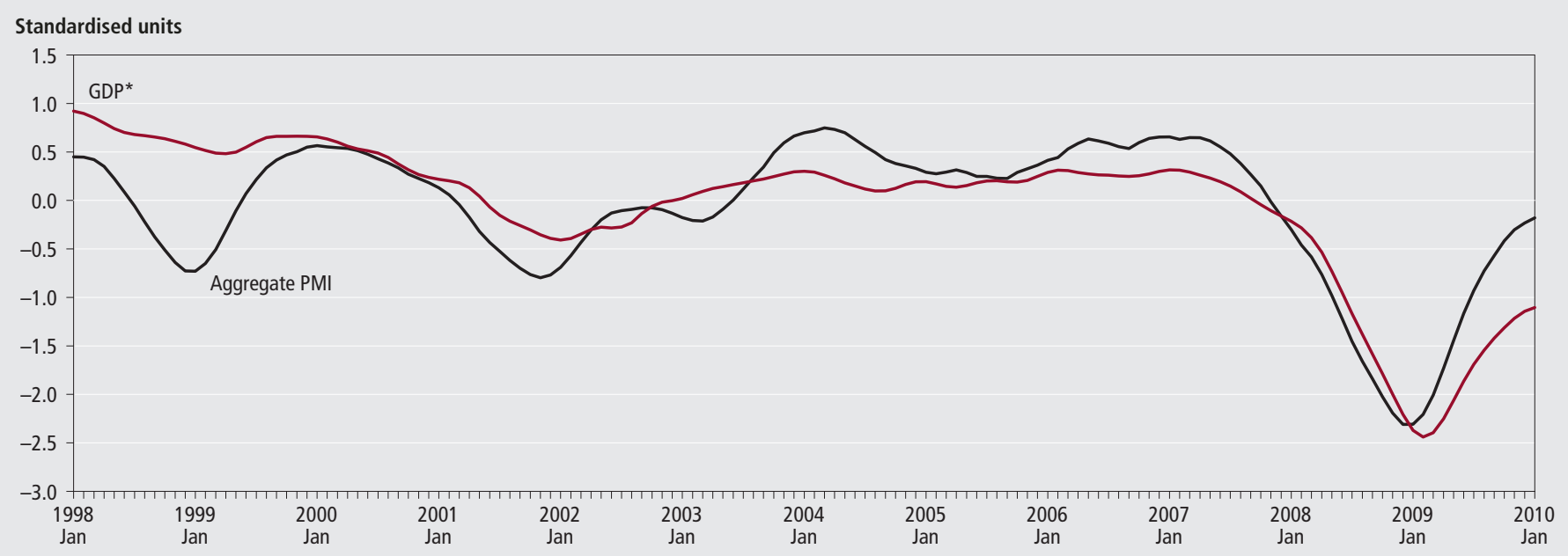

Source: ONS and Markit/CIPS

emerge simply if there is a broad consensus that things are improving - even if the improvement were deemed modest. For example, if all survey respondents were to report modest growth in the latest month the published balance statistic would be the same as if they all reported strong growth. Hence swings in PMI survey balances may reflect consensus as much as the magnitude of growth.

\section{Public sector net borrowing increases to 11.6 per cent of GDP in 2009/10}

- he most recent Public Sector Finances statistical bulletin for March 2010 is of particular interest as it coincides with the end of financial year 2009/10. As Figure 6 shows, in this latest financial year, the current budget balance deficit, which is the difference between the Government's current revenues and expenditures, has grown to 7.7 per cent of GDP $(£ 107.6$ billion). As a percentage of GDP this is the largest current budget deficit since the War. After the previous recession in the early 1990s the current budget deficit peaked at 6.3 per cent of GDP in 1993/94.

Figure 6 also shows the speed at which the current budget deficit has deteriorated in the last two financial years. In 2007/08, the current budget deficit was $£ 4.6$ billion ( 0.32 per cent of GDP). This rose significantly by around $£ 45$ billion to $£ 49$.7 billion (3.47 per cent of GDP) in 2008/09, before a further increase of $£ 60.0$ billion in the latest financial year.

Since the financial year 1977/78, public sector net investment has averaged around 1.5 per cent of GDP. However, in recent years this proportion has steadily risen to 4.0 per cent in $2009 / 10$. Adding this to the growing budget deficit in the last two financial years, has meant that Public Sector Net Borrowing (PSNB) has increased markedly (also shown in Figure 6).

ONS currently publishes two measures of PSNB. According to the overall measure, PSNB stood at $£ 152.8$ billion (10.9 per cent of GDP) in 2009/10. However, the headline measure, which excludes the impact of the Government's interventions in the financial sector, has shown a lager rise to $£ 163.4$ billion (11.6 per cent of GDP) in 2009/10. This compares to $£ 96.5$ billion (6.7 per cent of GDP) in 2008/09 and $£ 33.6$ billion (2.4 per cent of GDP) in 2007/08.

PSNB excluding financial interventions was introduced in the Pre-Budget Report 2009 and parallels the measure of Public Sector Net Debt (PSND) excluding financial interventions that was introduced in Budget 2008. The rationale is that much of the 


\section{Figure 6}

\section{Public sector net borrowing and its components}

Percentage of GDP

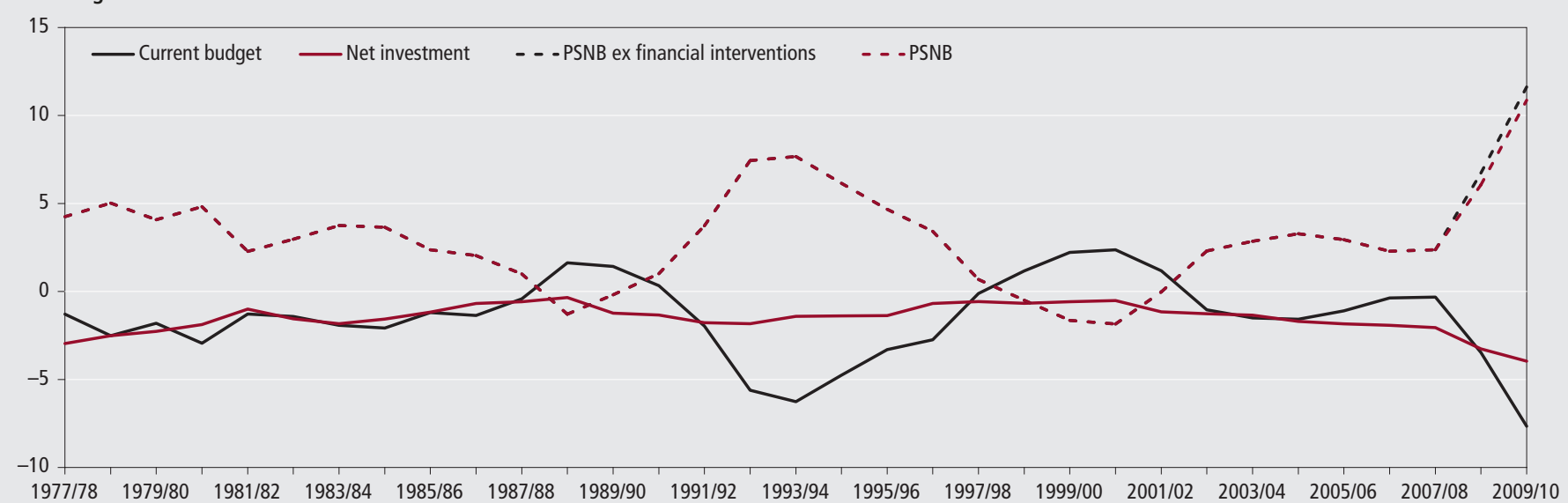

Source: Public sector finances

\section{Figure 7}

\section{Central government budget revenues in the last three financial years}

\section{$\mathrm{f}$ billions}

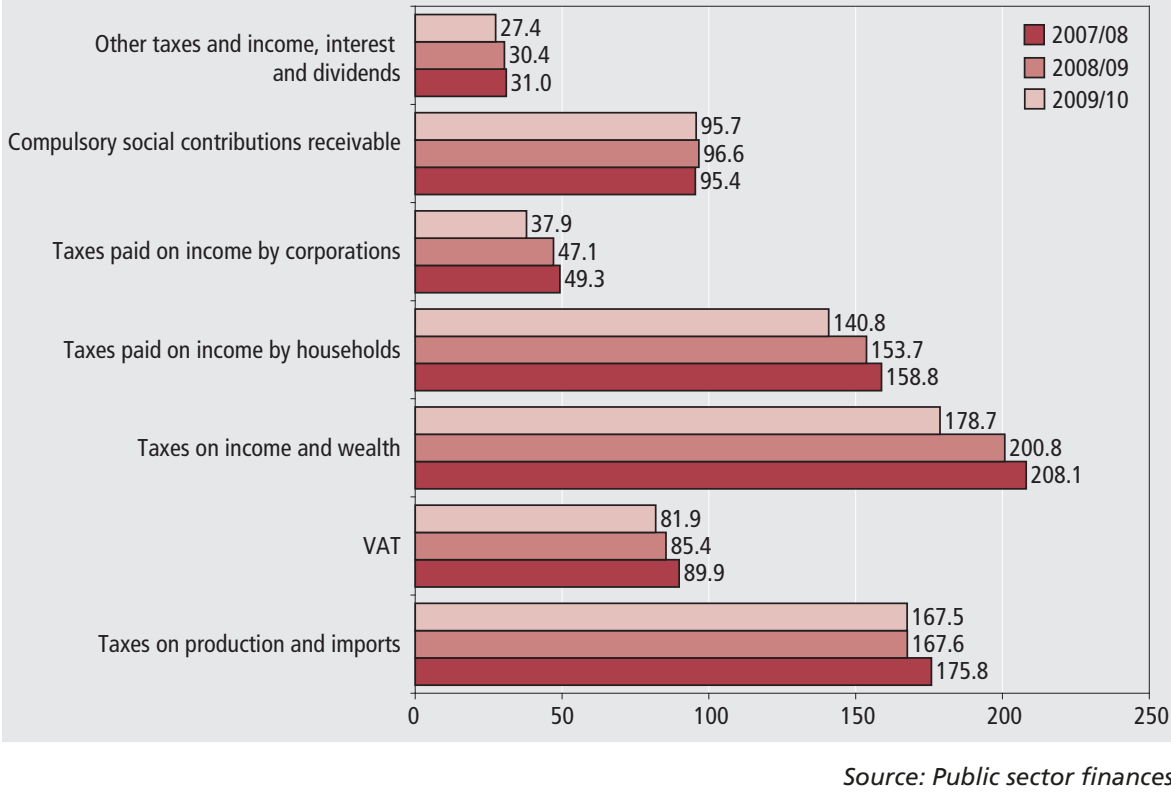

Figure 8

Central government budget expenditure and depreciation in the last three financial years

$\mathrm{f}$ billions

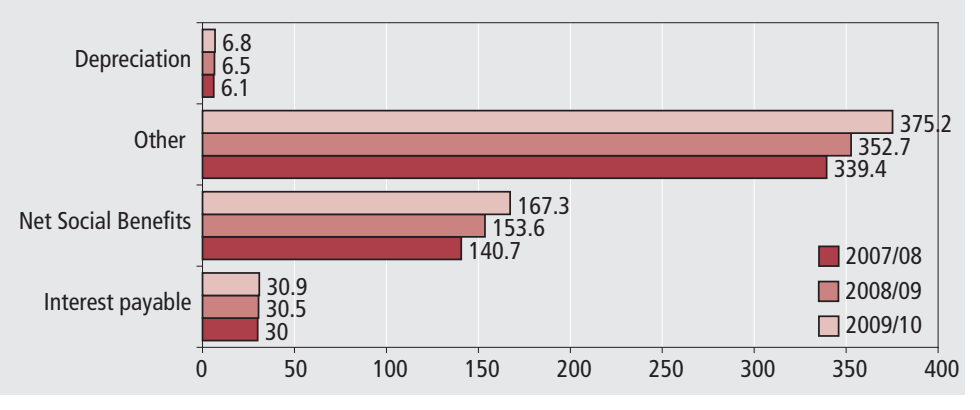

Source: Public sector finances
Government's intervention is regarded as temporary, for example, it intends to eventually divest itself of shareholdings and ownership in the banking sector. Therefore, these measures excluding interventions are considered to provide a better guide to the underlying state of public sector finances without 'temporary' distortions.

In terms of PSNB, it is clear from the figures that the Government's intervention has reduced net borrowing which is higher once the effects of interventions have been removed. Much of the Government's intervention has consisted of buying private sector financial assets, which although adds to net debt, has generated a flow of revenue that supports the current budget balance. For example, the operating surpluses and net-interest positions of banks now considered to be in the public ownership domain will be scored to the current budget. Net interest earnings from the Asset Purchase Facility and fees paid to the Special Liquidity Scheme (both operated by the Bank of England) are also added to the current budget.

Figure 7 and Figure 8 show how the current revenues and expenditure (including depreciation) of Central Government have changed over the last three financial years during which the current budget deficit and PSNB have increased.

Total revenues (Figure 7) have declined from $£ 510$ billion in $2007 / 08$ to $£ 495$ billion in $2008 / 09$ and then to $£ 469$ billion in 2009/10 - a total fall of over $£ 40$ billion during the course of the last two financial years. During this period, revenues on production and imports declined by around $£ 8$ billion, which is almost entirely accounted for by VAT revenues reflecting 


\section{Figure 9}

\section{Public Sector Net Debt}

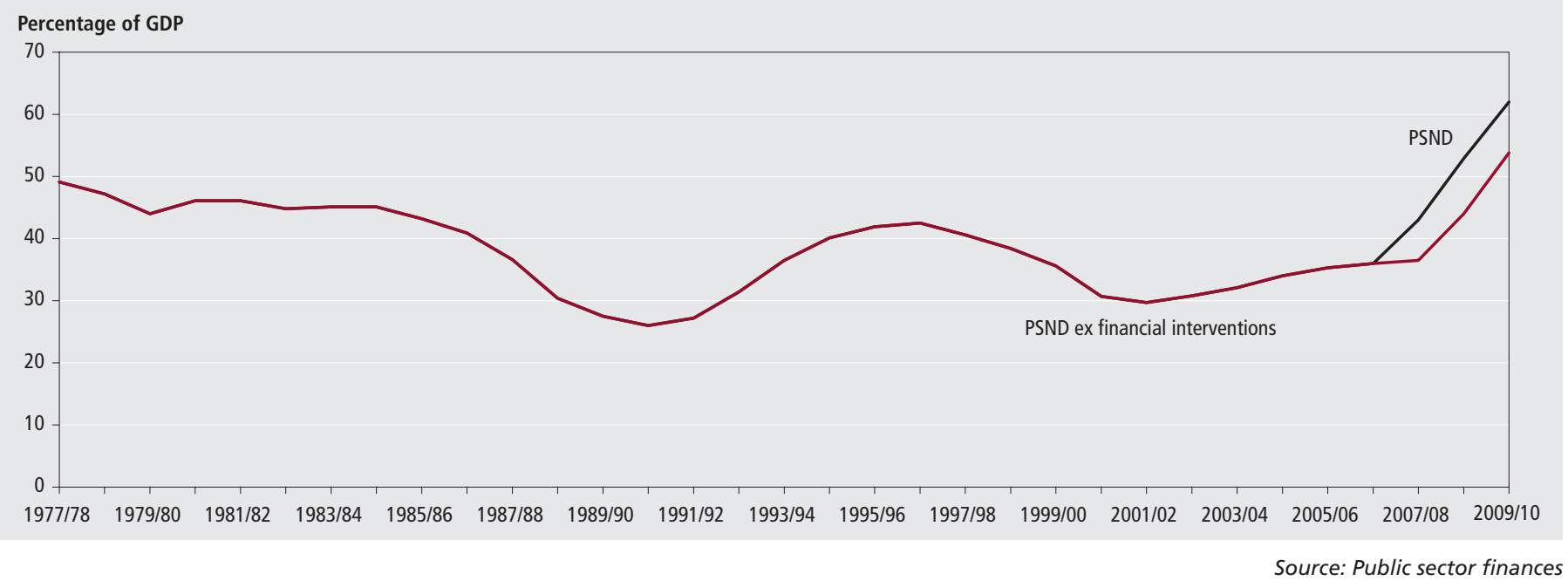

weaker spending and the temporary reduction in the rate of VAT from 17.5 per cent to 15 per cent between December 2008 and January 2010. Revenues from taxes and wealth declined by nearly $£ 30$ billion - a clear sign that the recession impacted strongly on economic activity and asset prices. Around $£ 18$ billion of this was accounted for by the household sector as the labour market weakened, and falling prices and lower turnover in the housing market reduced stamp duty revenues. Falling interest rates and equity prices also dampened non-labour sources of income. Just over $£ 11$ billion of the decline originated in the corporate sector, where the global recession impacted on operating surpluses and falling interest rates and equity prices on property (financial) income.

Figure 8 shows the pattern in current expenditure (including depreciation) over the same three financial years. Note that this does not include capital expenditure (public sector investment) which is shown in Figure 6 . There has been a strong increase in current expenditure from $£ 516$ billion in $2007 / 08$ to $£ 543$ billion in $2008 / 09$ and then to $£ 580$ billion in $2009 / 10$ - a total increase of around $£ 64$ billion in the last two financial years. Approximately $£ 27$ billion of this was accounted for by a rise in net social contributions - a reflection of the demise in the labour market and weak income growth in the recession. However, nearly $£ 36$ billion came from the 'other' category, and is likely to reflect more discretionary spending including stimulus spending.

ONS also publishes two measures of PSND. The measure excluding financial interventions is again treated as the headline figure for the same argument that these interventions are viewed as temporary. In the financial year 2009/10, PSND was 89.0 billion (62.0 per cent of GDP), but excluding financial interventions it was lower at $£ 771.6$ billion (53.8 per cent of GDP). These are presented in Figure 9.

In this case, the measure including financial interventions is worse than the headline measure as most of the Government's financial interventions have involved asset purchases or the acceptance of liabilities that have increased net debt. The net debt positions of Northern Rock and Bradford and Bingley are reflected in PSND but not PSND excluding interventions. At present the net debt of Lloyds Banking Group and RBS are yet to be scored to the public sector, but this is likely to further increase PSND compared to PSND excluding interventions. However, the Government's stated intention is to eventually return these organisations to the private sector so the impact on Public Sector Finances should be temporary.

Payments by the Financial Services Compensation Scheme (FSCS) and HM Treasury to compensate eligible depositors in the Icelandic banks operating in the UK and London Scottish Bank, or to contribute to the costs in resolving the Dunfermline Building Society currently add to PSND. However, as it is hoped these will eventually be recovered by realising the assets of the failed banks, it is viewed as temporary and not scored in the PSND excluding interventions measure.

As Figure 9 shows, even on the lower headline measure which excludes financial interventions, PSND has increased rapidly (by approximately $£ 250$ billion) in line with the growing level of PSNB over the last three financial years. In 2007/08 PSND excluding financial interventions was 36.5 per cent of GDP, this rose to 44.0 per cent of
GDP in $2008 / 09$ and then to 53.8 per cent in $2009 / 10$.

This is already higher than the peak of 42.5 per cent of GDP reached in 1996/97 after the previous recession. However, because PSND largely reflects the accumulated sum of current budget deficits it would be expected to increase further while PSNB remains positive. Economic growth is also important when thinking about PSND as a proportion of GDP as this also partly determines the size of net debt relative to the size of the economy that supports it.

\section{Unemployment rises to 8.0 per cent in December- February 2010}

igure 10 displays long time series

- of headline unemployment and employment rates in the UK.

In the three months December-February 2010 , unemployment climbed by 43,000 compared to the previous three month period to reach 2.5 million, corresponding to an unemployment rate of 8.0 per cent. This is the highest rate of unemployment recorded since the UK entered recession and unemployment first started to rise in Spring 2008. In the three months MarchMay 2008 unemployment stood at 1.6 million (5.2 per cent).

Compared to previous downturns, the 891,000 rise in the number of unemployed and the 2.8 percentage points increase in the rate of unemployment are lower, despite the fall in output being relatively severe. Between June-August 1990 and December-February 1993, total unemployment increased from 2.0 million (7.0 per cent) to 3.03 million (10.7 per cent) 


\section{Figure 10}

\section{Unemployment and employment rates}

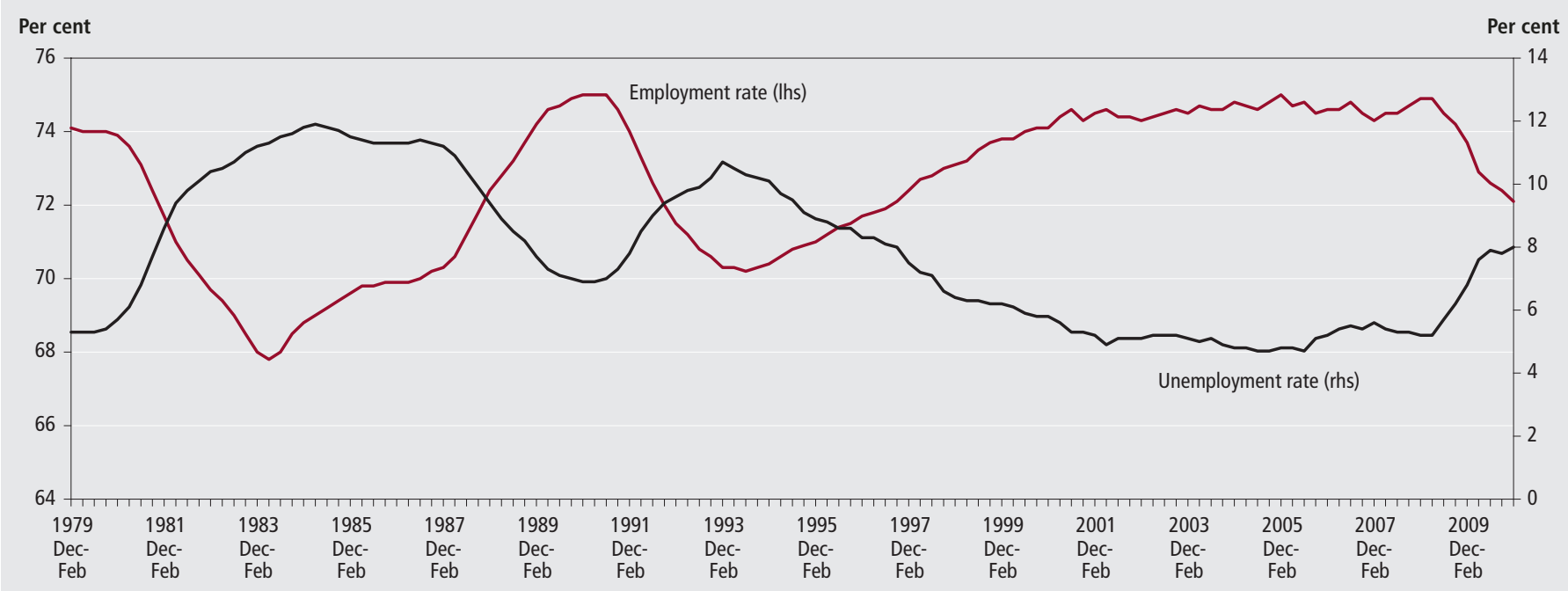

Source: Labour Market Statistics

- a total increase of just over 1.0 million (3.7 percentage points). In March-May 1979 total UK unemployment was 1.41 million (5.3 per cent), but three years later in March-May 1984 had increased to 3.28 million (11.9 per cent). This represented a total increase of 1.87 million (6.6 percentage points).

At present, and despite the latest quarterly increase, the rise in unemployment has been less marked than in previous recessions. However, the larger increases in unemployment in previous recessions partly reflected the fact that the labour market continued to weaken even after GDP had returned to growth. This was particularly the case in the early 1980 s recession when unemployment continued to rise for several years after the return to positive growth in GDP.

In December-February 2010,

employment was 89,000 lower than in the previous three-month period. As a result, the employment rate declined to a new recent trough of 72.1 per cent, the lowest rate since August-October 1996. The total fall in employment since the recent peak in March-May 2008 is 740,000.

In terms of the peak to trough fall in the number of employed and the lowest employment rate reached, the most recent downturn is not as bad as the two previous.

Between March-May 1990 and June-

August 1993 total employment fell by 1.65 million to reach a low employment rate of 70.2 per cent. And between DecemberFebruary 1980 and March-May 1983, total employment fell by 1.64 million to reach an employment rate low of 67.8 per cent.

Several factors that might explain why the pass through from falling output to the labour market has been weaker in the latest recession compared to the previous two have been proposed. There is some evidence that workers have accepted moderation in pay settlements and shorter working hours in order to preserve their employer's cash flow and sustain their own employment. Research published by the Bank of England (see Hackworth 2009) found that pay settlements averaged below 2 per cent in 2009 - with the recession and weak labour demand a key influence on settlements. Although there were relatively few instances of employees being forced to accept pay cuts, around 35 per cent in the private sector experienced a pay freeze in the last year. Walling and Clancy (2010) report on the increasing incidence of time-related underemployment in the current recession and the increasing share of part-time employees unable to find full-time work.

Businesses may also have held on to labour to a greater extent. In the services sector, which accounts for a growing share of total GVA, skilled labour inputs are relatively important. Therefore, in the downturn firms have to judge the extent to which labour might be cut in relation to spare capacity against the expected difficulty and cost in hiring and training skilled labour once business conditions improve. Sharp reductions in interest rates may have aided this form of labour hoarding, by reducing the costs of servicing debts and supporting cash flows it relieves the pressure to cut the wage bill. Furthermore, the incentive to push employees into early retirements has been made less attractive by large deficits in corporate pension schemes that have to be reported in greater detail in published company accounts.
Indirect taxes add 1.75 percentage points to the annual rate of $\mathrm{CPI}$ inflation

he Consumer Prices Index (CPI) was
3.4 per cent higher in March 2010
than the same month a year earlier

(Figure 11). Although the general direction of changes in consumer prices inflation in the last two years have reflected movements in energy prices - for instance motor fuels which are 24.6 per cent higher in March than last year are currently adding about 1.0 percentage point to annual CPI inflation rates - changes in indirect taxes have also had large and sustained effects.

ONS publishes two CPI measures that seek to remove the impact of indirect tax changes on the annual inflation rate to provide an underlying picture of inflation developments in the economy. CPIY is essentially the all items CPI with certain indirect taxes excluded. These include VAT, excise duties, insurance premium tax, air passenger duty and stamp duty on share transactions. Based on this measure CPIY inflation was 1.8 per cent in March. CPI-CT includes indirect taxes in the index, but holds them at constant values. Therefore, due to differences in weights, it will be similar but not exactly the same as CPIY measure. In March, annual inflation in CPI-CT was 1.6 per cent. As Figure 11 shows, CPIY and CPI-CT usually show strong co-movements. Based on the CPICT measure, ONS also publish a series that accounts for the contribution of indirect taxes to the annual change in CPI (which is basically CPI-CT minus CPI all items and also plotted in Figure 11). 


\section{Figure 11}

\section{Annual rates of $\mathrm{CPI}$, CPIY and CPI-CT inflation}

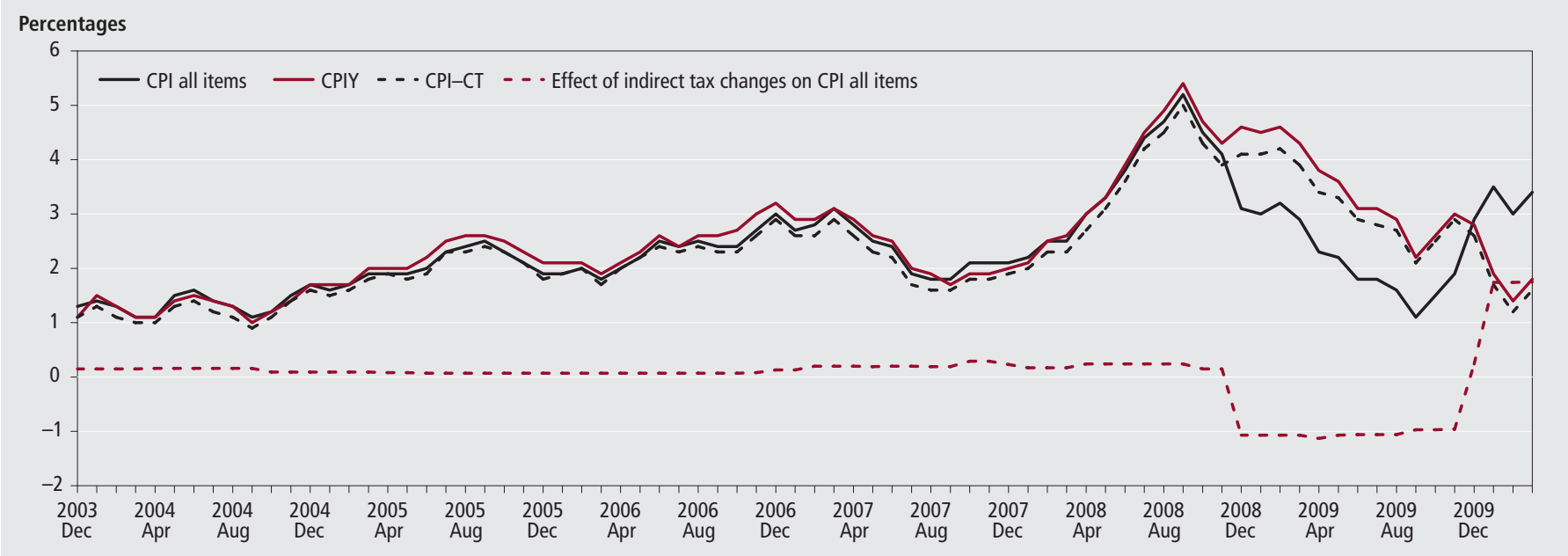

Source: Consumer Prices

CPI fell below the CPIY and CPI-CT annual inflation rates between December 2008 and January 2009 when VAT was temporarily reduced from 17.5 per cent to 15.0 per cent. As this reduction feeds into the price level for an entire year, and the annual inflation rate reflects the change over 12-months, its impact was to lower CPI inflation by about 1.0 percentage point during this period.

The reversion to the higher rate of VAT in January 2010 though has had a double positive effect on CPI inflation. If the VAT reduction had been permanent and reflected as such in price levels, it would have eventually fallen out of the inflation calculation after a year, hence CPI inflation would increase and converge back to CPIY and CPI-CT. This happened in December 2009 as shown in Figure 11. The impact of the increase in VAT in January 2010 would then raise inflation further, as seen by the movement of CPI above CPIY and CPI-CT. In March the all items CPI inflation rate was around 1.75 percentage points higher than the CPI-CT rate.

This positive innovation in the rate of CPI inflation will now remain in the index for a year, so will fall out of annual inflation calculations in January 2011 when CPI and CPIY and CPI-CT would be expected to converge once again. However, the exact impact will also depend on the extent to which changes in VAT have been passed onto consumer prices and also changes in other indirect taxes. But as Figure 11 shows, once the impact of indirect taxes has been removed underlying inflation in consumer prices is currently lower than the all items rate would imply.

\section{CONTACT}

C elmr@ons.gov.uk

\section{REFERENCES}

Ashley J, Driver R, Hayes S and Jeffery C (2005 'Dealing with data uncertainty', Bank of England Quarterly Bulletin, Spring

Butler J (2005) 'GDP doubts. What evidence?' HSBC Global Research

Chamberlin G (2008) 'Monitoring the coherence of ONS and Purchasing Managers' Index data' Economic and Labour Market Review (May), available at www.statistics.gov.uk/cci/article. asp? ID =1995
Cunningham A and Jeffery C (2007) 'Extracting a better signal from uncertain data', Bank of England Quarterly Bulletin, Autumn

Hackworth (2009) 'Recent developments in pay settlements' Bank of England Quarterly Bulletin (Q4), available at www.bankofengland.co.uk/publications/ quarterlybulletin/qb090403.pdf

Nardo M (2003) 'Quantification of qualitative survey data: a critical assessment', Journal of Economic Surveys, 17(5) pp 645-68

Tily $\mathrm{G}$ and Meader R 'Monitoring the quality of the National Accounts', Economic and Labour Market Review (March), available at www.statistics.gov.uk/cci/article. asp? ID $=1948$

Walling A and Clancy G (2010)

'Underemployment in the UK labour market' Economic and Labour Market Review

(February), available at www.statistics.gov.uk/cci/article. asp? $\mid \mathrm{D}=2360$ 